\title{
EXPERIMENTAL AND QUANTUM CHEMICAL STUDIES OF SOME DERIVATIVE OF DECAHYDROACRIDINEDIONE-1,8 AS CORROSION INHIBITOR OF STEEL 17 GS IN NS 4 SOLUTION
}

\author{
Tetyana Kalyn ${ }^{1}$; Liubomyr Poberezhny ${ }^{1}$; Dmytro Melnyk ${ }^{2}$ \\ ${ }^{1}$ Ivano-Frankivsk National Technical University of Oil and Gas, \\ Ivano-Frankivsk, Ukraine \\ ${ }^{2}$ Ivano-Frankivsk National Medical University, Ivano-Frankivsk,Ukraine
}

\begin{abstract}
Summary. The use of inhibitors remains one of the most effective and economically sound methods of corrosion protection in various aggressive environments. Since universal inhibitors do not exist, effective inhibitors or compositions should be developed for each individual case. The inhibitory properties of $N-p h e n y l-$ decahydroacridindiones $-1,8$ in groundwater imitats were investigated in this research. Inhibitory properties has been studied by the use of the electrochemical and gravimetric methods.
\end{abstract}

Key words: organic corrosion inhibitors, decahydroacridinedione, protonation.

https://doi.org/10.33108/visnyk_tntu2021.01.129

Received 27.01.2021

Statement of the problem. During operation, oil and gas equipment is subject to corrosion due to various factors, including corrosive impact of the environment. To prevent corrosion damage, various methods are used, among which the techniques of chemical inhibition of both inorganic and organic compounds have become widespread.

Analysis of available research. The main inhibitors of organic nature are the compounds containing atoms of nitrogen, oxygen and sulfur. Most frequently, nitrogencontaining compositions used for metal corrosion protection are aliphatic amines and their salts, amino alcohols, amino acids, nitromethanes, anilines [1]. Derivatives of pyridine [2-5], dihydropyridine [6], quinoline [7, 8], pyrazine [9], benzimidazole [10], acridine [11] demonstrate protective effect, mainly in acidic environments. Instead, it was found [2] that triazoles and benzotriazoles are more effective in neutral media and saline solutions. Effectiveness of the inhibitory impact of organic compounds is determined by their adsorption capacity on the metal surface due to the active groups [1]. Adsorption may depend on the interaction of the $\pi$-orbitals of the inhibitor with the d-orbitals of metal atoms on the surface, which leads to the formation of a film that protects against corrosion [12] and can manifest itself as physical or chemisorption [13].

For interpretation of the corrosion mechanism processes, theoretical research of the interrelation between structural and electronic parameters and corrosion inhibition effectiveness are used $[14,15]$.

Despite the large number of corrosion inhibitors, the search for new inhibitors and creation of compositions are carried out, which will be effective for particular conditions.

Objectives of the research is experimental and quantum-mechanic investigation of inhibitory properties of N-phoenildecahydroacriddindions-1,8 in NS4 medium.

Materials and methods. Compounds used as inhibitors (ing1, ing2) were synthesized according to the developed method [16]. The molecular formula of the synthesized compounds is shown in Fig. 1. Synthesized compounds - crystalline substances, insoluble in water, soluble 
in alcohols. Ethanol solutions of inhibitors were used for experimental studies of their anticorrosion properties.

Gravimetric experiments were carried out in a cylindrical vessel. The volume of the solution was $500 \mathrm{ml}$. Experimental specimens were made of steel 17GS in the form of plates measuring 50x10x3

$\mathrm{mm}$. Steel plates were degreased, dried and weighed on an analytical balance to the nearest $0.0001 \mathrm{~g}$. Studies were performed on imitation of groundwater NS4 of the following composition: $\mathrm{KCl}-0.122 \mathrm{~g} / \mathrm{l}, \mathrm{NaHCO}_{3}-0.483 \mathrm{~g} / \mathrm{l}, \mathrm{CaCl}_{2} \cdot 2 \mathrm{H}_{2} \mathrm{O}-0.181 \mathrm{~g} / \mathrm{l}, \mathrm{MgSO}_{4} \cdot 7 \mathrm{H}_{2} \mathrm{O}-$ $0.131 \mathrm{~g} / 1[17]$.

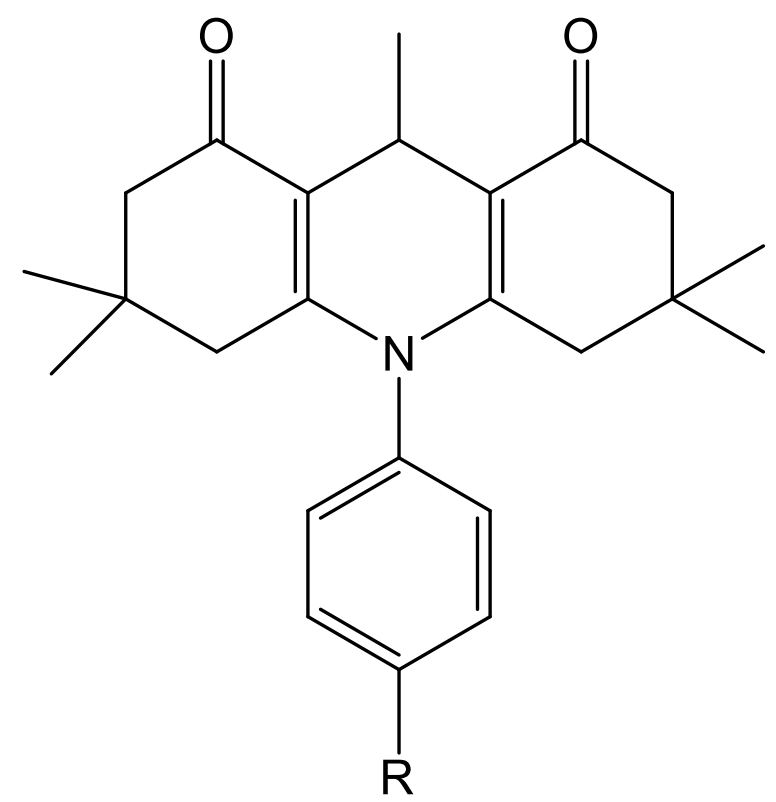

where $\mathrm{R}=\mathrm{H}$ (ing 1$), \mathrm{NO}_{2}$ (ing 2)

Figure 1. Chemical structure of inhibitors $\left(\mathrm{R}=\mathrm{H}\right.$ (inhibitor 1), $\mathrm{NO}_{2}$ (inhibitor 2)

Gravimetric experiments were carried out in a cylindrical vessel. The volume of the solution was $500 \mathrm{ml}$. Experimental specimens were made of steel 17GS in the form of plates measuring 50x10x3 mm. Steel plates were degreased, dried and weighed on an analytical balance to the nearest $0.0001 \mathrm{~g}$.

The exposure time was 168 hours. After the experiments, the degreased and dried plates were weighed on a weight with an accuracy of $0.001 \mathrm{~g}$. The corrosion rate $(K)$ was determined in $\mathrm{g} / \mathrm{m}^{2} \cdot \mathrm{h}$ by the formula:

$$
K=\frac{m_{1}-m_{2}}{S \times \tau}
$$

where $m_{l}$ is the weight of the plate before testing, $\mathrm{g}$;

$m_{2}$ is the weight of the plate before testing, g;

$S$ is the area of the plate, $\mathrm{m}^{2}$;

$\tau$ is the testing time, $\mathrm{h}$. studies.

The measurement result is the arithmetic mean of three parallel values of one series of

The degree of anti-corrosion $(\mathrm{Z})$ protection of the metal was determined by the formula: 


$$
Z=\frac{K-K_{\text {ing }}}{K} \times 100 \%
$$

where $K$ is corrosion rate without inhibitor; $K_{\text {ing }}$ is corrosion rate with inhibitor.

Investigations of the mechanism of the inhibitor action, evaluation of its effect on partial electrochemical processes on steel in the model media, determination of the corrosion rate of steel by the magnitude of the corrosion current were performed using the method of polarization curves. The experiments were performed on a MTech COR-410 potentiostat. Measurements of voltammograms were carried out within the potential of the working electrode $-1.6 \ldots+0.3 \mathrm{~V}$. The studies were performed in a three-electrode electrochemical cell with a working solution volume of $250 \mathrm{ml}$. The working electrode was made of $17 \mathrm{GS}$ steel with the area of $0.03 \mathrm{~cm}^{2}$, the reference electrode - chlorine silver, auxiliary - graphite. Electrode prepared for electrochemical studying, was placed in a cell with imitation groundwater NS4, kept for some time before the establishment of the equilibrium corrosion potential. The inhibitor was administered after pre-dissolving it in ethanol.

To investigate the possible correlation between the experimental inhibition efficiency and the electronic parameters of the molecules, the density functional theory (DFT) was applied using a hybrid exchange-correlation electron density functional in the generalized gradient approximation B3LYP with a standard set of basic functions 6-31G $(\mathrm{d}, \mathrm{p})$.

Results and discussion. According to the results of studies using ing 1 with a concentration of $0.3 \mathrm{~g} / \mathrm{l}$, the corrosion rate was $0.062 \mathrm{~g} / \mathrm{m}^{2} \cdot$ hours, the protective effect is $39.6 \%$, when using inhibitor 2 with a concentration of $0.3 \mathrm{~g} / \mathrm{l}$, the corrosion rate was $0.080 \mathrm{~g} / \mathrm{m}^{2} \cdot$ hours, protective effect was $27.6 \%$ (table 1 ).

Table 1

Protective effectiveness of corrosion inhibitors inNS4 (gravimetric)

\begin{tabular}{|c|c|c|c|}
\hline Inhibitor & $\begin{array}{c}\text { Concentration of } \\
\text { inhibitor, } \mathrm{g} / \mathrm{l}\end{array}$ & $\begin{array}{c}\text { Corrosion rate, } \\
\mathrm{g} / \mathrm{m}^{2} \cdot \text { hours }\end{array}$ & $\begin{array}{c}\text { Degree of protection } \\
\text { of metal against } \\
\text { corrosion, } \%\end{array}$ \\
\hline ing 1 & 0,3 & 0,062 & 39,6 \\
\hline ing 2 & 0,3 & 0,080 & 27,6 \\
\hline
\end{tabular}

As can be seen from the results, the inhibition effect of corrosion was negligible. Probably, in the mineralized environment inhibition occurs due to the adsorption of molecules on the metal surface.

Polarization studies were performed to study the effect of inhibitors on the anodic and cathodic reactions of the corrosion process of 17GS steel in NS4 groundwater imitation. According to the results of electrochemical studies, potentiodynamic curves were constructed (Fig. 2).

The study was performed without inhibitor (curve 1), with the addition of alcohol solution ing1 (curve 2), ing 2 (curve 3). The corresponding concentrations were $0.3 \mathrm{~g} / \mathrm{l}$. The potential without current is smoothly shifted towards negative values and is set in 10-15 minutes after immersion in the working solution. The shift of the equilibrium potential to the negative area, which indicates the activation of corrosion processes in the pipeline steel is recorded.

The obtained electrochemical parameters, namely, the corrosion potential $\mathrm{E}_{\text {corr }}$, the corrosion current density $\mathrm{I}_{\text {corr }}$ and the calculated protective efficiency are given in table 2 . 
Experimental and quantum chemical studies of some derivative of decahydroacridinedione-1,8 as corrosion inhibitor of steel $17 \mathrm{GS}$ in $\mathrm{NS}_{4}$ solution

Table 2

Electrochemical parameters of 17GS steel and protective effectiveness of corrosion inhibitors inNS4 (electrochemical)

\begin{tabular}{|c|c|c|c|}
\hline Inhibitor & $\mathrm{E}_{\text {corr }}$ & $\mathrm{I}_{\text {corr }}, \mathrm{mA} / \mathrm{cm}^{2}$ & $\mathrm{EI}, \%$ \\
\hline- & $-1,033$ & 1,995 & - \\
\hline ing 1 & $-0,934$ & 0,562 & 71 \\
\hline ing 2 & $-0,911$ & 1,585 & 20 \\
\hline
\end{tabular}

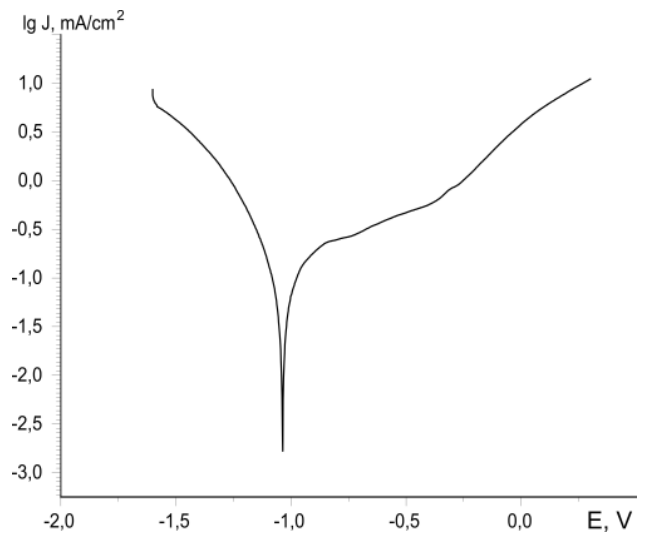

$\mathrm{a}$

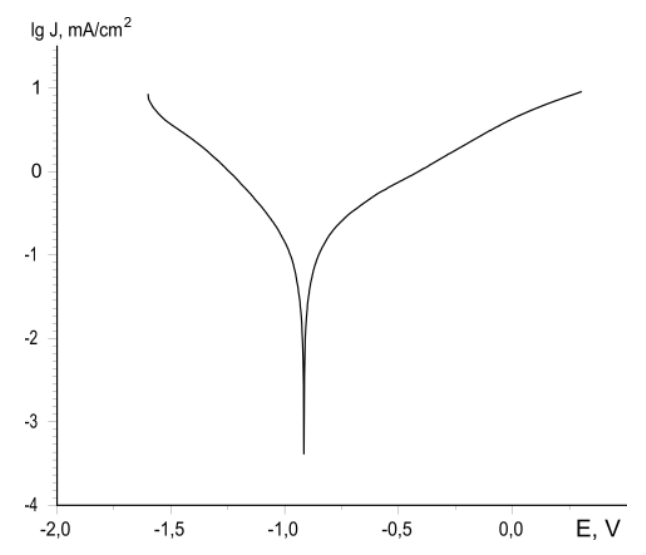

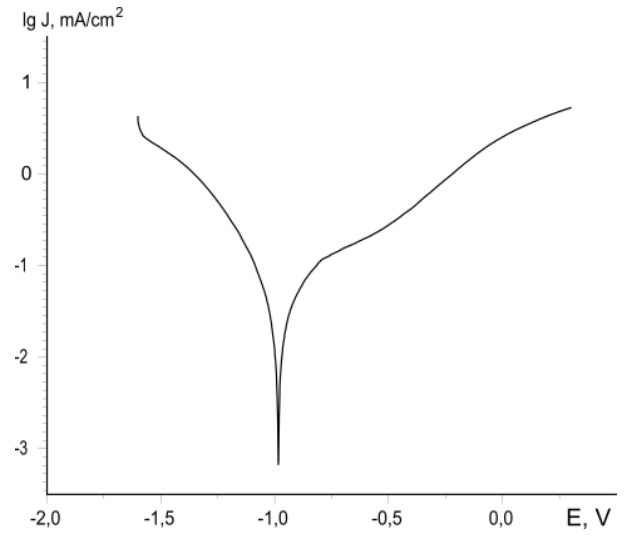

b

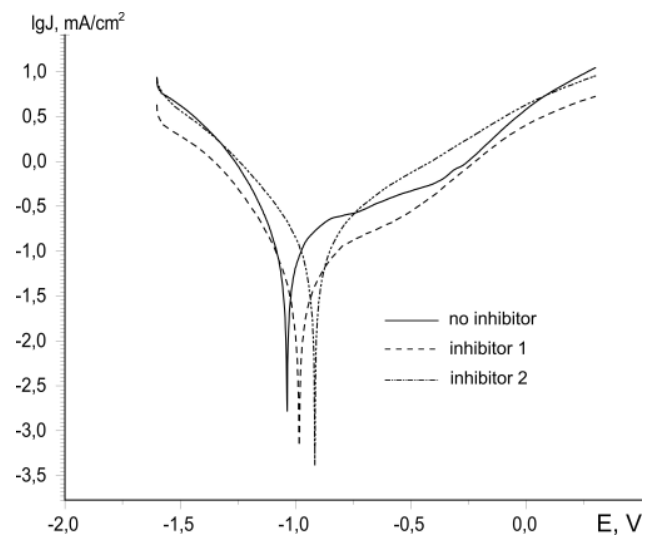

Figure 2. Potentiodynamic curves of 17GS pipe steel in NS4: 1) blank; 2) ing 1; 3) ing 2

As it turned out, when using inhibitors, the corrosion potential shifts to the range of positive values. If the $\mathrm{E}_{\text {corr }}$ shift exceeds $85 \mathrm{mV}$, the inhibitor can act as anodic one. Therefore, both compounds inhibit the anodic process of dissolving steel. The obtained results show that the corrosion current density decreases in the presence of the ing1 inhibitor compared to the uninhibited solution in both the cathode and anode areas. Instead, for ing 2, despite a significant shift in the corrosion potential, the current density is practically not reduced.

The inhibition efficiency was determined by the equation:

$$
\mathrm{EI} \%=\frac{I_{\text {corr }}-I_{\text {corr ing }}}{I_{\text {corr }}} \cdot 100 \%
$$


The calculated parameters and the effectiveness of corrosion inhibition were determined to establish the relationships that may exist between them. Possible correlations between experimental inhibition efficiency and electronic parameters such as the highest occupied $\left(\mathrm{E}_{\mathrm{HOMO}}\right)$ and lowest unoccupied $\left(\mathrm{E}_{\mathrm{LUMO}}\right)$ molecular orbitals and their difference $\left(\Delta \mathrm{E}_{\mathrm{L}-\mathrm{H}}\right)$, as well as some structural characteristics were investigated.

It is known [18] that the limiting orbital energies of Hомо and LUMO inhibitor molecules are related to the ionization potential $(I)$ and electron affinity $(A)$ by the ratios:

$$
\begin{gathered}
I=-E_{\text {Номо }}, \\
A=-E_{\text {LUMO }} .
\end{gathered}
$$

Absolute electronegativity $(\chi)$, absolute hardness $(\eta)$, softness $(\sigma)$ of the inhibitor molecule were calculated by the equations [19]:

$$
\begin{gathered}
\chi=\frac{I+A}{2}, \\
\eta=\frac{I-A}{2}, \\
\sigma=\frac{1}{\eta} .
\end{gathered}
$$

The number of transferred electrons $(\Delta \mathrm{N})$ was calculated by equation [18]:

$$
\Delta N=\frac{\chi_{F e}+\chi_{c o m p}}{2\left(\eta_{F e}-\eta_{c o m p}\right)}
$$

where $\chi_{\mathrm{Fe}}$ and $\chi_{\text {comp }}$ stand for the absolute electronegativity of iron and compounds, and $\eta_{F e}$ and $\eta_{\text {comp }}$ stand for the absolute stiffness of iron and compounds.

In this research, the theoretical value of $\chi_{\mathrm{Fe}}=7 \mathrm{eV} / \mathrm{mol}, \chi_{\text {comp }}=0 \mathrm{eV} / \mathrm{mol}$ were used. The absolute electrophilicity index is determined by the equation [20]:

$$
\omega=\frac{\mu^{2}}{2 \eta}
$$

where $\mu$ is chemical potential, whilst $\mu=-\chi$.

A more reactive nucleophile is characterized by less values of $\mu, \omega$; and, conversely, a more reactive electrophile is characterized by higher value of $\mu, \omega$.

The interaction between the inhibitor and the metal occurs due to the interaction of electrons with the orbitals occupied by the inhibitor (mainly from HOMO), with d-orbitals of the metal, and through the transition of electrons from d-orbital of the metal to unoccupied orbitals (mainly to LUMO). Thus, Еномо determines the trend of donor properties of molecules [21], which leads to increased adsorption of the inhibitor on the metal surface and, consequently, better inhibition efficiency. Instead, ELUMO indicates the ability of a molecule to accept electrons. Therefore, the lower value of ELUMO indicates better ability to accept electrons, which will also increase the adsorption of the inhibitor on the metal surface and, accordingly, better inhibition efficiency.

The ability of the inhibitor to bind to the metal surface increases with increasing HOMO levels and decreasing LUMO energy values. 
Figure 3 shows that HOMO is distributed on the decahydroacridine fragment of the molecules, and ing1 has higher energy. Instead, the presence of a nitro group in ing2, which has a significant acceptor effect, dramatically reduces the energy of LUMO. This causes the LUMO ing2 to become an orbital localized on the nitrophenyl fragment. Although the nitro group is not involved in the formation of HOMO ing2, it also slightly reduces its energy.

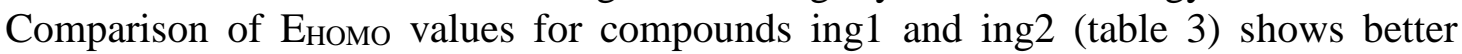
inhibition efficiency by compound ing 1 , which is consistent with the experimental value. ELUMO shows a discrepancy with the experiment. The energy gap $\left(\Delta_{\mathrm{EL}-\mathrm{H}}\right)$ is an important parameter of the functional ability of the inhibitor molecule to adsorb on the metal surface. As $\Delta_{\mathrm{EL}-\mathrm{H}}$ decreases, the reactivity of the molecule increases, which leads to better inhibition efficiency [22]. From the table it is seen that inhibitor ing2 has a smaller energy gap value of $1.261 \mathrm{eV}$, which should lead to better inhibition.

One of the main characteristics of the chemical activity of atoms and molecules is the ionization energy (I). High ionization energy (I) indicates high stability and chemical inertness and vice versa [23]. The lower ionization energy of $4.653 \mathrm{eV}$ for ing 1 indicates its higher inhibition efficiency compared to $4.950 \mathrm{eV}$ for ing2, which corresponds to the results of experiments.

Table 3

Calculated quantum-chemical parameters of ing1 and ing2

\begin{tabular}{|c|c|c|c|c|}
\hline Compound & $\mathrm{E}_{\text {HOMO }}, \mathrm{eB}$ & ELUMO $_{\text {LB }}$ & $\Delta \mathrm{E}_{\mathrm{L}-\mathrm{H}}, \mathrm{eB}$ & $\mathrm{z}, \%$ \\
\hline ing1 & $-4,653$ & $-2,115$ & 2,539 & 39,6 \\
\hline ing2 & $-4,950$ & $-3,689$ & 1,261 & 27,6 \\
\hline
\end{tabular}

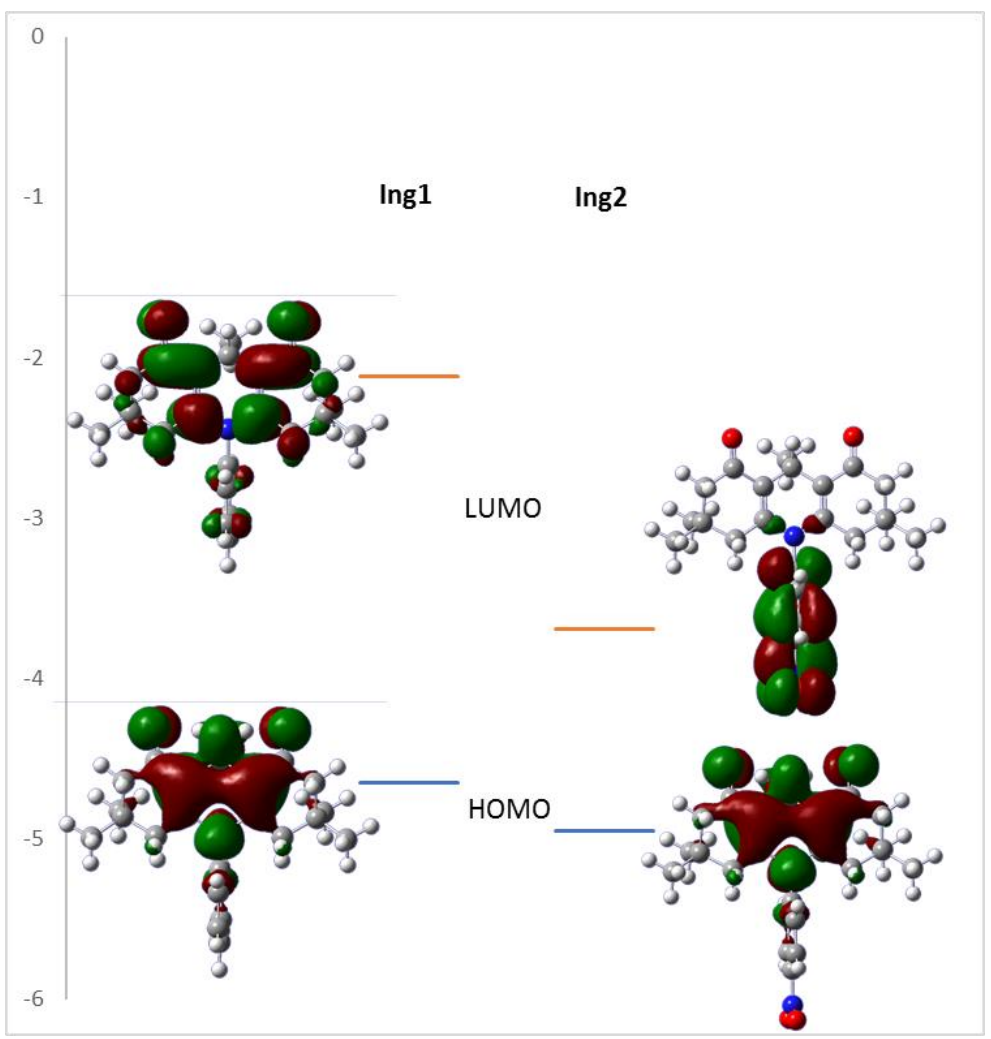

Figure 3. Frontier molecular orbitals of ing1 and ing2 calculated at B3LYP/6-31G(d,p) 
From the table 4 the value of electronegativity $(\chi)$ for ing1 is less than ing2. According to the principle of equalization of Sanderson's electronegativity [24], the compound ing1 was expected to have a greater inhibitory effect.

Absolute rigidity $(\eta)$ and softness $(\sigma)$ are important properties for determining molecular stability and reactivity. The rigid molecule has a larger energy gap (high value of $\Delta_{\mathrm{EL}-\mathrm{H}}$ ) [25]. It is generally expected that an inhibitor with lower absolute rigidity value (respectively, with higher absolute softness value) has higher inhibition efficiency [26], which is not consistent in this study.

Table 4

Calculated quantum-chemical parameters of electronegativity, molecular stability and reactivity for ing $1 \mathrm{i}$ ing 2

\begin{tabular}{|c|c|c|c|c|c|c|c|c|}
\hline Compound & $I, \mathrm{eB}$ & $A, \mathrm{eB}$ & $\chi, \mathrm{eB}$ & $\eta, \mathrm{eB}$ & $\omega$ & $\sigma$ & $\Delta N$ & $\mathrm{z}, \%$ \\
\hline ing1 & 4,653 & 2,115 & 3,384 & 1,269 & 4,511 & 0,788 & 1,424 & 39,6 \\
\hline ing2 & 4,950 & 3,689 & 4,319 & 0,631 & 14,791 & 1,586 & 2,126 & 27,6 \\
\hline
\end{tabular}

The number of transferred electrons $(\Delta \mathrm{N})$, which characterizes the ability of inhibitors to transfer electrons to the metal surface [27], is greater for ing2, the inhibitory properties of which should be higher.

Thus, based on the conducted experimental and computational studies, it can be stated

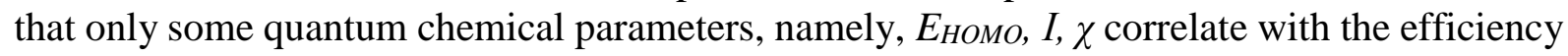
of experimental inhibition.

Conclusions. The investigated derivatives of N-phenyl-1,8-dioxodecahydroacridines show weak protective properties against low-alloy steel in NS4 medium. The presence of nitrogen atoms and two carbonyl groups in the structure of molecules - probable coordination centers on the metal surface, did not lead to the expected high results.

Analysis of theoretical calculations of quantum chemical parameters and inhibitory

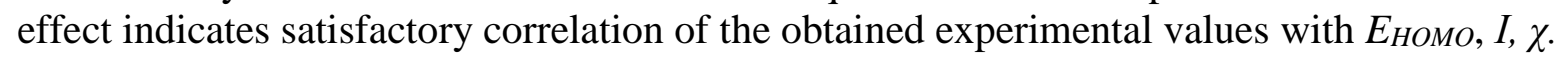

\section{References}

1. Alsabagh A. M., Migahed M. A., \& Awad H. S. (2006). Reactivity of polyester aliphatic amine surfactants as corrosion inhibitors for carbon steel in formation water (deep well water). Corrosion Science. 48 (4). P. 813-828. DOI: https://doi.org/10.1016/j.corsci.2005.04.009

2. Desimone M. P., Grundmeier G., Gordillo G., \& Simison S. N. (2011). Amphiphilic amido-amine as an effective corrosion inhibitor for mild steel exposed to $\mathrm{CO} 2$ saturated solution: polarization, EIS and PM-IRRAS studies. Electrochimica Acta. 56 (8). P. 2990-2998. DOI: https://doi.org/10.1016/j.electacta.2011.01.009

3. Yavorskyi A., Tsykh V., Poberezhnyi L. (2017) Methodology for geodynamic risk determination in the areas with broaching engineering structures. Scientific Journal of TNTU (Tern.). Vol. 87. No. 3. P. 26-37. DOI: https://doi.org/10.33108/visnyk_tntu2017.03.026

4. Ansari K. R., Quraishi M. A., Singh A. Pyridine derivatives as corrosion inhibitors for N80 steel in $15 \%$ HCl: Electrochemical, surface and quantum chemical studies. Measurement. 2015. Vol. 76. P.136-147. DOI: https://doi.org/10.1016/j.measurement.2015.08.028

5. Ansari K. R., Quraishi M. A., Singh A. Corrosion inhibition of mild steel in hydrochloric acid by some pyridine derivatives: An experimental and quantum chemical study. Journal of Industrial and Engineering Chemistry. 2015. Vol. 25. P. 89-98. DOI: https://doi.org/10.1016/j.jiec.2014.10.017 
Experimental and quantum chemical studies of some derivative of decahydroacridinedione-1,8 as corrosion inhibitor of steel $17 \mathrm{GS}$ in $\mathrm{NS}_{4}$ solution

6. Mourya P., Singh P., Rastogi R. B., Singh M. M. Inhibition of mild steel corrosion by 1,4,6-trimethyl-2oxo-1,2-dihydropyridine-3- carbonitrile and synergistic effect of halide ion in $0.5 \mathrm{M} \mathrm{H} 2 \mathrm{SO}$. Applied Surface Science. 2016. Vol. 380. P. 141-150. DOI: https://doi.org/10.1016/j.apsusc.2016.01.263

7. Hassan N., Ramadan A. M., Khalil S. [et.all] Experimental and computational investigations of a novel quinoline derivative as a corrosion inhibitor for mild steel in salty water. Colloids and Surfaces A: Physicochemical and Engineering Aspects. 2020. Vol. 607/ 125454. DOI: https://doi.org/10.1016/j.colsurfa.2020.125454

8. Verma C., Quraishi M. A., Ebenso E. E. Quinoline and its derivatives as corrosion inhibitors: A review. Surfaces and Interfaces. 2020. Vol. 21, 100634. DOI: https://doi.org/10.1016/j.surfin.2020.100634

9. Obot I. B., Gasem Z. M. Theoretical evaluation of corrosion inhibition performance of some pyrazine derivatives. Corrosion Science. 2014. Vol. 83. P. 359-366. DOI: https://doi.org/10.1016/j.corsci.2014.03.008

10. Wang X., Yang H., Wang F. An investigation of benzimidazole derivative as corrosion inhibitor for mild steel in different concentration $\mathrm{HCl}$ solutions. Corrosion Science. 2011. Vol. 53. 1. P. 113-121. DOI: https://doi.org/10.1016/j.corsci.2010.09.029

11. Salghi, R., Ben Hmamou, D., Ebenso, E.E. [et all.] 2, 10 - dimethylacridin - $9(10 \mathrm{H})$ - one as new synthesized corrosion inhibitor for $\mathrm{C} 38$ steel in $0.5 \mathrm{M} \mathrm{H} 2 \mathrm{SO} 4$. International Journal of Electrochemical Science. 2015. Vol. 10. (1). P. 259-271.

12. Poberezhny L., Hrytsanchuk A., Halushko N., Poberezhna L. (2019) Influence of pH rate on corrosion of gas pipelines in soils with high mineralization. Scientific Journal of TNTU (Tern.). Vol. 95. No 3. P. 41-48. DOI: https://doi.org/10.33108/visnyk_tntu2019.03.041

13. Bouklah M., Hammouti B., Lagrenée M. and Bentiss F. Thermodynamic Properties of 2,5-bis(4methoxyphenyl)-1,3,4-oxadiazole as a Corrosion Inhibitor for Mild Steel in Normal Sulfuric Acid Medium. Corrosion Science. 2006. Vol. 48. P. 2831-2842. DOI: https://doi.org/10.1016/j.corsci.2005.08.019

14. Wang D., Li S., Ying Y., Wang M., Xiao H. and Chen Z. Theoretical and Experimental Studies of Structure and Inhibition Efficiency of Imidazoline Derivatives. Corrosion Science. 1999. Vol. 41. No. 10. P. 19111919. DOI: https://doi.org/10.1016/S0010-938X(99)00027-X

15. Udhayakala P., Rajendiran T. V. and Gunasekaran S. Theoretical Approach to the Corrosion Inhibition Efficiency of Some Pyrimidine Derivatives Using DFT Method. Journal of Computational Methods in Molecular Design. 2012. Vol. 2. No. 1. P. 1-15.

16. Poberezhny L. (2017) Effect of ionic strength on electro corrosion in chloride and chloride-sulfate environments. Scientific Journal of TNTU (Tern.). Vol. 88. No.4. P. 49-55. DOI: https://doi.org/10.33108/visnyk_tntu2017.04.049

17. Benmoussat A., Hadjel M. Corrosion behavior of low carbon line pipe steel in soil environment. Eurasian Chemico-Technological Journal. 2005. Vol. 7. No. 2. P. 147-156. DOI: https://doi.org/10.18321/ectj626

18. Pearson R. G. Absolute Electronegativity and Hardness: Application to Inorganic Chemistry. Inorganic Chemistry. 1988. Vol. 27. No. 4. P. 734-740. DOI: https://doi.org/10.1021/ic00277a030

19. Parr R. G., Pearson R. G. Absolute Hardness: Companion Parameter to Absolute Electronegativity. Journal of the American Chemical Society. 1983. Vol. 105. No. 26. P. 7512-7516. DOI: https://doi.org/10.1021/ja00364a005

20. Parr R. G., Szentpaly L. V., Liu S. Electrophilicity Index. Journal of the American Chemical Society. 1999. Vol. 121. No. 9. P. 1922-1924. DOI: https://doi.org/10.1021/ja983494x

21.E. S. H. El Ashry, A. El Nemr, S. A. Esawy, S. Ragab Corrosion Inhibitors: Part II: Quantum Chemical Studies on the Corrosion Inhibitions of Steel in Acidic Medium by Some Triazole, Oxadiazole and Thiadiazole Derivatives. Electrochimica Acta. 2006. Vol. 5. No. 19. P. 3957-3968. DOI: https://doi.org/10.1016/j.electacta.2005.11.010

22. Issa R. M., Awad M. K., Atlam F. M. Quantum Chemical Studies on the Inhibition of Corrosion of Copper Surface by Substituted Uracils. Applied Surface Science. 2008. Vol. 255. No. 5. P. $2433-2441$. DOI: https://doi.org/10.1016/j.apsusc.2008.07.155

23. Sandip K. R., Islam N. and Ghosh D. G. Modeling of the Chemico-Physical Process of Protonation of Molecules Entailing Some Quantum Chemical Descriptors. Journal of Quantum Information Science. 2011. Vol. 1. P. 87-95. DOI: https://doi.org/10.4236/jqis.2011.12012

24. Geerlings P., Proft F. D. Chemical Reactivity as Described by Quantum Chemical Methods. International Journal of Molecular Sciences. 2002. Vol. 3. No. 4. P. 276-309. DOI: https://doi.org/10.3390/i3040276 
25. Obi-Egbedi, N. O., Obot I. B., El-khaiary M. I. [et all] Computational Simulation and Statistical Analysis on the Relationship between Corrosion Inhibition Efficiency and Molecular Structure of Some Phenanthroline Derivatives on Mild Steel Surface. International Journal of Electrochemical Science. 2011. Vol. 6. No. 11. P. 5649.

26. Ebenso E. E., Isabirye D. A., Eddy N. O. Adsorption and Quantum Chemical Studies on the Inhibition Potentials of Some Thiosemicarbazides for the Corrosion of Mild Steel in Acidic Medium. International Journal of Molecular Sciences. 2010. Vol. 11. No. 6. P. 2473-2498. DOI: https://doi.org/10.3390/ijms

27. Lukovits I., Kalman E., Zucchi F. Corrosion Inhibitors - Correlation between Electronic Structure and Efficiency. Corrosion. 2001. Vol. 57. No. 1. P. 3-8. DOI: https://doi.org/10.5006/1.3290328

УДК 620.19

\title{
ЕКСПЕРИМЕНТАЛЬНІ ТА КВАНТОВО-ХІМІЧНІ ДОСЛІДЖЕННЯ ДЕЯКИХ ПОХІДНИХ ДЕКАГІДРОАКРИДИНДІОНУ-1,8 ЯК ІНГІБІТОРІВ КОРОЗІЇ СТАЛІ 17 ГС У РОЗЧИНІ NS4
}

\section{Тетяна Калинㅜ; Любомир Побережний'ㄹ Дмитро Мельник²}

\author{
${ }^{1}$ Івано- Франківський начіональний технічний університет нафти і газу, \\ Івано-Франківськ, Украӥна \\ ${ }^{2}$ Івано-Франківський національний медичний університет, \\ Івано-Франківськ, Україна
}

\begin{abstract}
Резюме. У прочесі експлуатачіі нафтогазове устаткування зазнає корозійного впливу, зумовленого різними факторами, в тому числі корозійною активністю середовища. Метою роботи $\epsilon$ експериментальні та кванотово-хімічні дослідження інгібуючих властивостей $N$-фенілдекагідроакридиндіонів-1,8 у середовищі NS4. Дослідження механізму дії інгібітора, оцінювання його впливу на париіальні електрохімічні процеси на сталі у модельному середовищі, визначення швидкості корозії сталі за величиною корозійного струму виконані з використанням методу поляризаційних кривих. Вимірювання вольтамперограм здійснювали в межах потениіалу робочого електрода - 1,6...+0,3В. Робочий електрод виготовлений зі сталі 17ГС площею $0,03 \mathrm{~cm}^{2}$, електрод порівняння - хлорсрібний, допоміжнийграфітовий. Підготовлений для електрохімічних досліджень електрод вмімували в комірку з імітатом грунтової води NS4, витримували певний час до встановлення рівноважного потенціалу корозії. Інгібітор вводили, попередньо розчинивщи його в етанолі. Встановлено, щуо при використанні інгібіторів потенціал

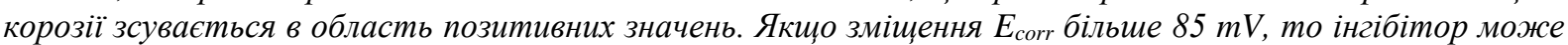
діяти як анодний. Отже, обидві сполуки гальмують анодний процес розчинення сталі. Отримані результати свідчать, щзо густина корозійного струму зменшується в присутності інгібітора ing 1 порівняно з неінгібованим розчином як в катодній, так $і$ анодній області. Взаємодія між інгібітором $і$ металом відбувається внаслідок взаємодії електронів з орбіталями, зайнятими інгібітором, $3 d$ орбіталями металу, а також через перехід електронів з $d$-орбіталі металу до незайнятих орбіталей інгібітора. Аналіз теоретичних розрахунків квантово-хімічних параметрів та інгібуючого ефекту вказує

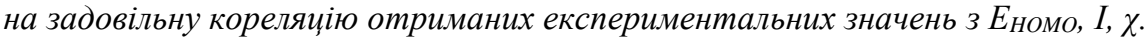

Ключові слова: органічні інгібітори корозії, декагідроакридиндіон, протонування.
\end{abstract}

